\section{Analisis Pengaruh Tingkat Inflasi Dan Tingkat Bagi Hasil Terhadap Profitabilitas Pada Bank Umum Syariah Di Indonesia}

Inflation Rate and Profit Sharing Rate on Sharia Commercial Bank Profitability

\author{
(Studi Kasus Pada Pt Bank Muamalat Indonesia,Tbk., Pt \\ Bri Syariah, Tbk.,Pt Bank Bukopin Syariah, Tbk., Pt Bni \\ Syariah, Tbk., Dan Pt Bca Syariah, Tbk. Periode 2011-2018)
}

\author{
Destiana Dwi Nita, Muhammad Ariffin dan Neni Nurisniani \\ ${ }^{123}$ Institut Bisnis dan Informatika Kesatuan Bogor \\ Email :
}

Submitted: MARET 2021

Accepted: JUNI 2021

This study aims to determine the effect of Inflation Rate and Profit Sharing Rate on Sharia Commercial Bank Profitability in Indonesia. The independent variable (independent) in this study is the level of inflation and the level of profit sharing, while profitability is the dependent variable. In this study, researchers used Return on Assets (ROA) as an indicator for profitability.

The method used is descriptive method and verification method. The data used are secondary data sourced from Financial Statements that have been published by Bank Muamalat Indonesia, Bank Rakyat Indonesia (BRI) Syariah, Bank Bukopin Syariah, Bank Negara Indonesia (BNI) Syariah, and Bank Central Asia (BCA) Syariah. The data analysis technique used is panel data regression analysis and classic assumption test, because the data used are secondary data and the type of data used is a combination of cross section data and time series data. Data processing techniques using the help of Eviews 9 program.

Based on data analysis that has been done using panel data regression and classical assumption tests, it is found that the Inflation Rate has a negative and significant effect on Return on Assets (ROA), this result is evidenced by the significance value of 0,0012 and the regression coefficient shows a figure of 0,0817. Level of Profit Sharing is positive and significant effect, this result is evidenced by the significance value of 0.0000 and the regression coefficient shows a figure of 0,1644. The coefficient of determination (R-square) value is $77,26 \%$.

Keywords: Inflation Rate, Profit Sharing Rate, Return on Assets (ROA).

\title{
ABSTRAK
}

Penelitian ini bertujuan untuk mengetahui pengaruh Tingkat Inflasi dan Tingkat Bagi Hasil terhadap Profitabilitas Bank Umum Syariah di Indonesia. Variabel bebas (independen) dalam penelitian ini adalah Tingkat Inflasi dan Tingkat Bagi Hasil, sedangkan profitabilitas sebagai variabel terikat (dependen). Dalam penelitian ini, peneliti menggunakan Return on Assets (ROA) sebagai indikator untuk profitabilitas.

Metode yang digunakan yaitu metode deskriptif dan metode verifikatif. Data yang digunakan merupakan data sekunder yang bersumber dari Laporan Keuangan yang telah dipublikasikan oleh Bank Muamalat Indonesia, Bank Rakyat Indonesia (BRI) Syariah, Bank Bukopin Syariah, Bank Negara Indonesia (BNI) Syariah, dan Bank Central Asia (BCA) Syariah. Teknik analisis data yang digunakan yaitu analisis regresi data panel dan uji asumsi klasik, karena data yang digunakan merupakan data sekunder dan jenis data yang digunakan yaitu gabungan data cross section dan data time series. Teknik pengolahan data menggunakan bantuan program Eviews 9.

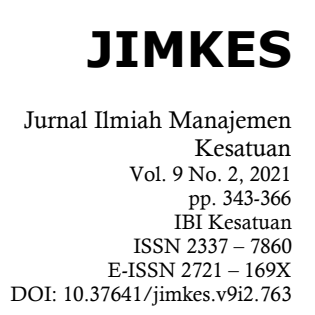


Inflation Rate and Profit Sharing Rate on Sharia Commercial Bank Profitability

\section{4}

\section{PENDAHULUAN}

Perbankan memiliki peranan yang sangat penting dalam menunjang berjalannya roda perekonomian dan pembangunan mengingat sebagai lembaga intermediasi, penyelenggara transaksi pembayaran, serta alat pengendalian kebijakan moneter.Padakrisis moneter ditahun 1998 bank-bank konvensional banyak yang dilikuidasi karena kegagalan pada sistem bunganya.Sementara perbankan yang menerapkan sistem syariah dapat tetap berdiri dan mampu bertahan. Tidak hanya itu, pada saat krisis ekonomiglobalyang terjadi pada akhir triwulan 2008 karena nilai tukar rupiah melemah, bank syariah tetap stabil memberikan keuntungan, kenyamanan bagi nasabahnya. Pengembangan industri perbankan syariah di Indonesia semakin memiliki landasan hukum yang memadai dan akan mendorong pertumbuhannya secara lebih cepat dengan diberlakukannya Undang-Undang No. 21 Tahun 2008 tentang perbankan syariah, serta tingginya jumlah penduduk umat Islam di Indonesia merupakan peluang yang sangat besar bagi bank syariah dalam meraih nasabah.Pada kegiatan operasionalnya, bank syariah tidak terlepas dari faktor internal dan faktor eksternal.

Faktor eksternal yang harus diperhatikan yaitu kondisi perekonomian di Indonesia, salah satunya tingkat inflasi yang tinggi. Pada krisis moneter tahun 1998 inflasi mencapai 77,63\% dan saat krisis ekonomi global tahun 2008 inflasi mencapai 11,06\% (sumber: Badan Pusat Statistik Indonesia) karena dipengaruhi naiknya harga-harga pokok dan nilai tukar rupiah yang melemah, hal ini menyebabkan kemampuan membeli masyarakat menjadi terbatas dan kemampuan berinvestasi berkurang karena sebagian masyarakat menggunakan dananya untuk berjaga-jaga ketika inflasi sedang naik yang membuat harga barang-barang pokok naik.Perubahan tersebut akan berdampak pada kegiatan operasional bank syariah dan dapat mempengaruhi kinerja keuangan perusahaan, dampaknya bagi bank yaitu karena jumlah dana dari masyarakat yang dihimpun akan semakin berkurang dan sebagian dana perusahaan ada yang berasal dari pembiayaan bank sehingga nantinya akan mempengaruhi kinerja bank syariah dalam memperoleh pendapatan dan menghasilkan profit karena adanya beberapa kredit atau pembiayaan yang mengalami macet. Selain itu, perusahaan riil enggan menambah modal usahanya yang pada akhirnya akan berdampak pada turunnya profitabilitas bank syariah.

Berdasarkan data inflasi yang bersumber dari Bank Indonesia, tingkat inflasi selama delapan tahun kebelakang turun dan naik. 
Tabel 1. Data Tingkat Inflasi Indonesia

\begin{tabular}{|c|c|}
\hline Tahun & Tingkat Inflasi (\%) \\
\hline 2011 & $5,38 \%$ \\
\hline 2012 & $4,28 \%$ \\
\hline 2013 & $6,97 \%$ \\
\hline 2014 & $6,42 \%$ \\
\hline 2015 & $6,38 \%$ \\
\hline 2016 & $3,53 \%$ \\
\hline 2017 & $3,81 \%$ \\
\hline 2018 & $3,20 \%$ \\
\hline \multicolumn{2}{|c|}{ (Sumber: Data Inflasi Bank Indonesia (Data Diolah)) }
\end{tabular}

Hal yang membedakan perbankan syariah dengan perbankan konvensional adalah prinsip pembagian laba yang diterapkan oleh bank syariah. Dalam perbankan syariah tidak menganut sitem bunga, tetapi menganut sistem bagi hasil. Bagi hasil merupakan alternatif pengganti bunga pada bank konvensional, yaitu pembagian atas hasil usaha yang dibiayai oleh bank syariah dan pembagian keuntungannya disepakati diawal. Saat tingkat suku bunga di bank konvensional sedang meningkat, nasabah akan cenderung melakukan pembiayaan di bank syariah karena sistem bagi hasil yang diterapkan, dan tidak terpengaruh oleh peningkatan sistem bunga tersebut. Pada sistem bagi hasil, kinerja bank syariah menjadi transparan kepada nasabah, sehingga nasabah dapat memonitor kinerja bank syariah atas jumlah bagi hasil yang diperoleh. Apabila jumlah keuntungan meningkat, maka bagi hasil yang diterima nasabah juga akan meningkat, demikian pula sebaliknya, apabila jumlah keuntungan menurun, bagi hasil ke nasabah juga akan menurun, sehingga ini menjadi adil bagi pihak bank dan nasabah. Dalam bank syariah, hubungan yang dibentuk bukan hubungan antara kreditur dan debitur melainkan antara penyandang dana (shahibul maal) dengan pengelola dana (mudharib) yang berupa hubungan kemitraan. Maka keuntungan pada bank syariah diperoleh dari bagi hasil (profit sharing) atas penggunaan dana oleh pihak peminjam. Bagi hasil ini dapat diaplikasikan pada produk pembiayaan di bank syariah yaitu Mudharabah dan Musyarakah. Mudharabah adalah sebuah bentuk kemitraan di mana salah satu mitra (shahibul-maal) yang menyediakan sejumlah modal tertentu, sedangkan mitra yang lain (mudharib) menyediakan keahlian usaha dan manajemen untuk menjalankan ventura, perdagangan, industri atau jasa dengan tujuan mendapatkan laba. Musyarakah merupakan suatu bentuk organisasi usaha di mana dua orang atau lebih menyumbangkan pembiayaan dan manajemen usaha, dengan proporsi sama atau tidak sama. Keuntungan dibagi menurut perbandingan yang sama atau tidak sama, sesuai kesepakatan antara para mitra, dan kerugian akan dibagikan menurut proporsi (Pramono, 2017). Tingkat bagi hasil merupakan bentuk return dari kontrak investasi, dari waktu ke waktu, tidak pasti dan tidak tetap. Besar kecilnya perolehan kembali tergantung pada hasil usaha yang benar terjadi. Dengan tingkat bagi hasil yang tinggi nasabah akan lebih tertarik untuk meminjam dana karena akan mendapatkan keuntungan yang lebih dari bagi hasil tersebut, dengan begitu pihak bank syariah akan termotivasi dan juga memilki modal lebih dari keuntungan yang didapat untuk menyalurkan pembiayaan berbasis bagi hasil. Tingkat bagi hasil yang tinggi dan mengalami peningkatan menunjukan bahwa bank syariah berhasil dan efesien dalam mengelola dananya. Produk pembiayaan di bank syariah merupakan salah satu faktor internal yang mempengaruhi kinerja keuangan bank syariah, karena banyaknya nasabah yang melakukan pembiayaan akan meningkatkan profit karena dapat menambahkan asset dan bisa disalurkan kembali untuk nasabah.

Berdasarkan data tingkat bagi hasil yang bersumber dari laporan keuangan pada website masing-masing bank, tingkat bagi hasil selama delapan tahun kebelakang mengalami naik turun.
Inflation Rate and Profit Sharing Rate on Sharia Commercial Bank Profitability

345 
Inflation Rate and Profit Sharing Rate on Sharia Commercial Bank Profitability

346 
Berdasarkan latar belakang yang telah diuraikan sebelumnya, maka identifikasi masalah dalam penelitian ini dapat diuraikan sebagai berikut:

1. Bagaimana pengaruh tingkat inflasi terhadap profitabilitas bank umum syariah di Indonesia?

2. Bagaimana pengaruh tingkat bagi hasil terhadap profitabilitas bank umum syariah di Indonesia?

3. Bagaimana pengaruh tingkat inflasi dan tingkat bagi hasil terhadap profitabilitas bank umum syariah di Indonesia?

Sesuai dengan masalah yang telah diuraikan, maka maksud dan tujuan dari penelitian ini adalah: (1) Untuk mengetahui pengaruh antara tingkat inflasi terhadap profitabilitas bank umum syariah di Indonesia. (2) Untuk mengetahui pengaruh antara tingkat bagi hasil terhadap profitabilitas bank umum syariah di Indonesia. (3) Untuk mengetahui pengaruh antara tingkat inflasi dan tingkat bagi hasilBank Indonesia terhadap profitabilitas bank umum syariah di Indonesia.

\section{Kerangka Pemikiran}

Kerangka pemikiran teoritis merupakan landasan teoritis yang dibangun dan bersumber dari berbagai literatur, dapat berupa hasil penelitian sebelumnya, bersumber dari buku-buku pengetahuan, artikel-artikel ilmiah pada jurnal nasional dn jurnal internasional, artikel yang bersumber dari web internet yang dikelola oleh organisasi atau lembaga, dan sebagainya.

Kerangka pemikiran konseptual merupakan suatu hubungan antara konsep satu terhadap konsep lainnya dari masalah yang ingin diteliti. Kerangka pemikiran yang dirumuskan penulis adalah:

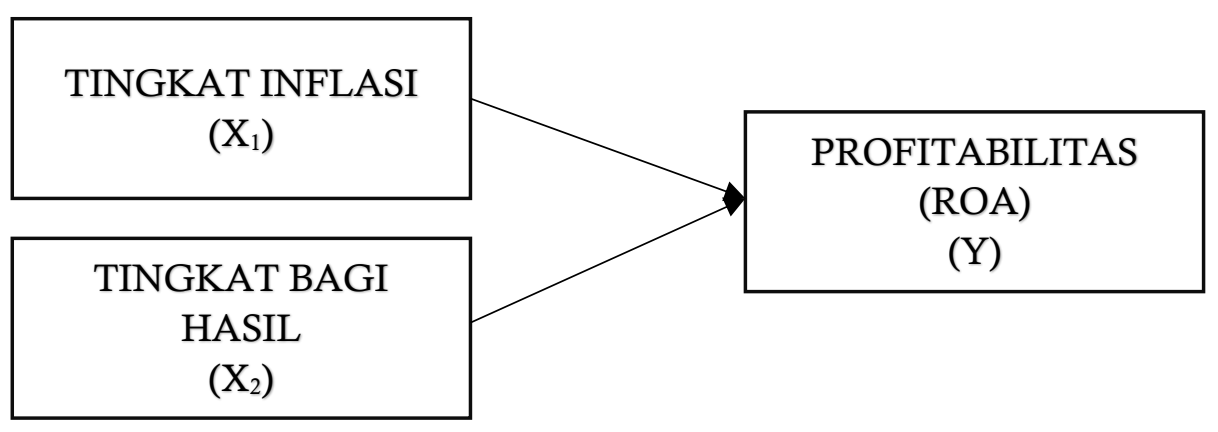

Gambar 1. Kerangka Pemikiran Konseptual

\section{METODE PENELITIAN}

Dalam penelitian ini metode yang digunakan yaitu metode penelitian deskriptif dan verifikatif dengan pendekatan kuantitatif. Metode deskriptif digunakan untuk mengetahui kondisi tingkat inflasi, tingkat bagi hasil, dan profitabilitas (ROA) pada Bank Umum Syariah yang terdaftar di Otoritas Jasa Keuangan (OJK) periode 2011-2018. Metode verifikatif digunakan untuk menjelaskan atau menganalisis bagaimana pengaruhtingkat inflasi dan tingkat bagi hasil secara terhadap profitabilitas (ROA).

Berdasarkan metode yang telah diuraikan diatas, penulis bermaksud mengumpulkan datadata yang berkaitan dengan masalah yang diteliti sehingga akan diperoleh data-data yang menunjang penyusunan laporan penelitian. Adapun pendekatan dalam penelitian ini yaitu menggunakan pendekatan kuantitatif. Metode penelitian dengan pendekatan kuantitatif digunakan dalam penelitian ini, karena data yang menjadi objek dalam penelitian ini merupakan data-data kuantitatif seperti tingkat inflasi, tingkat bagi hasil, dan profitabilitas (ROA).

Operasionalisasi Variabel. Operasionalisasi variabel merupakan salah satu unsur penelitian yang menjelaskan bagaimana cara mengukur dari masing-masing variabel. Variabel bebas
Inflation Rate and Profit

Sharing Rate on Sharia

Commercial Bank

Profitability 
Inflation Rate and Profit Sharing Rate on Sharia Commercial Bank Profitability

dalam penelitian ini berupa Inflasi dan Bagi Hasil. Variabel terikat dalam penelitian ini adalah Profitabilitas. Data sekunder yang digunakan dalam penelitian ini adalah data panel yaitu penggabungan data cross section dan time series.Berdasarkan sumber dari ojk.go.id tercatat hingga Maret 2020 ini ada 14 Bank Umum Syariah (BUS) yang beroperasi di Indonesia.

Tabel 4. Bank Umum Syariah

\begin{tabular}{|c|l|}
\hline No. & \\
\hline 1 & PT Bank Aceh Syariah \\
\hline 2 & PT BPD Nusa Tenggara Barat Syariah \\
\hline 3 & PT Bank Muamalat Indonesia \\
\hline 4 & PT Bank Victoria Syariah \\
\hline 5 & PT Bank BRI Syariah \\
\hline 6 & PT Bank Jabar Banten Syariah \\
\hline 7 & PT Bank BNI Syariah \\
\hline 8 & PT Bank Syariah Mandiri \\
\hline 9 & PT Bank Mega Syariah \\
\hline 10 & PT Bank Panin Dubai Syariah \\
\hline 11 & PT Bank Syariah Bukopin \\
\hline 12 & PT BCA Syariah \\
\hline 13 & PT Bank Tabungan Pensiunan Negara Syariah \\
\hline
\end{tabular}

(Sumber: Statistik Perbankan Syariah, OJK)

Teknikpengambilan sampel yang digunakan adalah purposive sampling dengan teknik penentuan sampel berdasarkan kriteria tertentu, yaitu Bank Umum Syariah (BUS)yang tergolong bank devisa maupun non devisa dan Bank Umum Syariah (BUS) yang memiliki kelengkapan data selama periode pengamatan berdasarkan variabel yang ditelitipada periode waktu 2011-2018. Berdasarkan kriteria pemilihan sampel di atas, Bank Umum Syariah (BUS) yang memenuhi kriteria untuk menjadi sampel adalah lima Bank Umum Syariah (BUS) untuk periode 2011-2018 yaitu PT Bank Muamalat Indonesia, PT Bank Rakyat Indonesia (BRI) Syariah, PT Bank Bukopin Syariah, PT Bank Negara Indonesia (BNI) Syariah, dan PT Bank Central Asia (BCA) Syariah.Pengumpulan data tidak lain dari suatu proses pengadaan data untuk keperluan penelitian. Metode pengumpulan data sangat erat hubungannya dengan masalah penelitian yang ingin dipecahkan.Metode pengumpulan data ialah teknik atau cara-cara yang dapat digunakan oleh peneliti untuk mengumpulkan data (Boyke, 2014). Untuk mengumpulkan data tersebut dapat dilakukan dengan teknik:

1. Studi Lapangan (Field Research)

Menurut Danang Sunyoto (2013:22), pengertian studi lapangan merupakan "Studi lapangan adalah suatu metode yang dilakukan oleh peneliti dengan cara pengamatan langsung terhadap kegiatan yang dilakukan oleh perusahaan". Untuk studi lapangan terdiri dari:

a. Wawancara (Interview)

Menurut S. Nasution (2010) wawancara adalah suatu bentuk komunikasi atau percakapan yang bertujuan untuk memperoleh informasi dalam keadaan saling berhadapan atau melalui telepon.

b. Dokumentasi

Menurut Djaman Satori dan Aan Komariah (2011) dengan teknik dokumentasi, peneliti dapat memperoleh informasi bukan dari orang sebagai sumber, tetapi memperoleh informasi dari macam-macam sumber tertulis atau dari dokumen yang ada pada informan dalam bentuk peninggalan budaya dan karya pikir. 
c. Observasi

Menurut Djam'an Satori dan Aan Komariah (2011) pengamatan terhadap suatu objek yang diteliti baik secara langsung maupun tidak langsung untuk memperoleh data yang harus dikumpulkan dalam penelitian untuk mengetahui keberadaan objek, situasi , konteks dan maknanya dalam upaya mengumpulkan data penelitian.

2. Studi Kepustakaan (Library Research)

Studi kepustakaan berkaitan dengan kajian teoritis dan referensi lain yang berkaitan dengan nilai, budaya dan norma yang berkembang pada situasi sosial yang diteliti, selain itu studi kepustakaan sangat penting dalam melakukan penelitian, hal ini dikarenakan penelitian tidak akan lepas dari literatur-literatur ilmiah. Data diperoleh dari data yang relevan terhadap permasalahan yang akan diteliti dengan melakukan studi pustaka lainnya seperti buku, jurnal, artikel, peneliti terdahulu.

3. Internet (Browsing)

Merupakan metode pengumpulan data yang berasal dari website dan situs resmi suatu instansi. Dengan metode ini penulis memperoleh data dan menemukan artikel-artikel yang berkaitan dengan apa yang penulis butuhkan sebagai bahan pertimbangan dalam melakukan penulisan proposal skripsi ini sehingga penilis mendapatkan informasi dan pengetahuan baru yang sebelumnya belum diketahui.

Dalam melakukan penelitian mengenai analisis pengaruh tingkat inflasi dan tingkat bagi hasil terhadap profitabilitas bank, teknik pengumpulan data yang digunakan yaitu observasi secara tidak langsung, studi kepustakaan (library research) dan internet (browsing).

Metode Analisis Data. Metode analisis data merupakan tahapan proses penelitian dimana data yang sudah dikumpulkan di manage untuk diolah dalam rangka menjawab rumusan masalah. Secara garis besar, cara menganilisis data untuk beberapa penelitian dapat diaplikasikan dengan teknik statistik yang merupakan data kuantitatif. Menurut Sugiyono (2012), teknik penelitian kuantitatif dapat diartikan sebagai suatu metode penelitian dengan landaskan pada filsafat positivisme, digunakan untuk meneliti populasi atau sampel.

Sedangkan analisis dengan teknik tematik merupakan analisis data kualitatif. Menurut Sugiyono (2017) metode penelitian kualitatif adalah suatu metode penelitian yang berlandaskan pada filsafat positivisme, yang digunakan untuk meneliti pada kondisi objek yang alamiah, (sebagai lawannya adalah eksperimen) yang dimana peneliti merupakan sebagai instrumen kunci, dari pengambilan sampel sumber data yang dilakukan dengan cara purposive dan snowball, teknik pengumpulan trianggulasi, analisa data yang bersifat induktif atau kualitatif, dan hasil penelitian kualitatif lebih menekan pada makna dari generalisasi. Dalam penelitian ini metode analisis data yang digunakan yaitu analisis data kuantitatif.

Paradigma Penelitian. Paradigma penelitian menunjukan hubungan antara variabel yang diteliti. Dalam penelitian ini, penulis menguji pengaruh Tingkat Inflasi dan Tingkat Bagi Hasil terhadap Profitabilitas (ROA) bank syariah. Penelitian ini menggunakan dua variabel bebas yaitu Tingkat Inflasi dan Tingkat Bagi Hasil serta variabel terikat yaitu Profitabilitas (ROA) bank syariah.
Inflation Rate and Profit

Sharing Rate on Sharia

Commercial Bank

Profitability 
Inflation Rate and Profit Sharing Rate on Sharia Commercial Bank Profitability

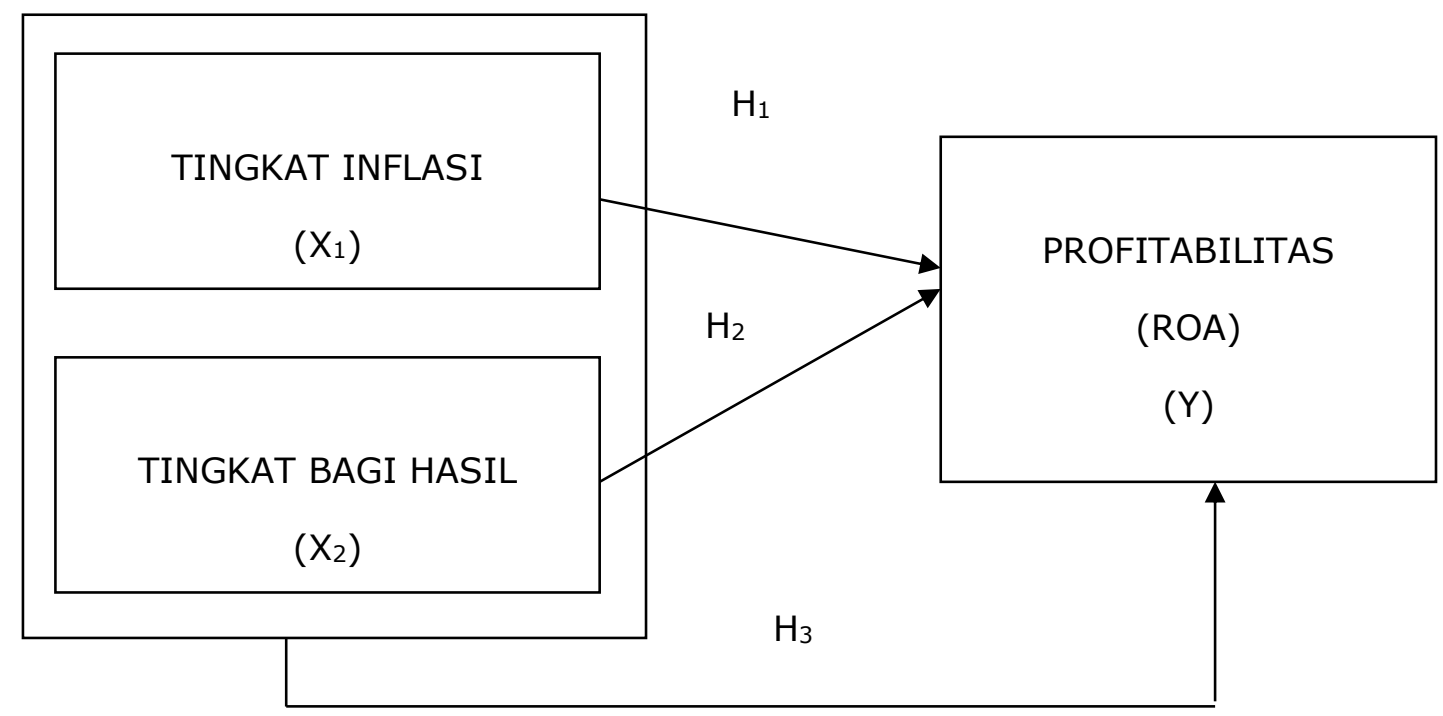

\section{Gambar 2. Paradigma Penelitian}

Hipotesis Penelitian. Menurut Dantes (2012), hipotesis adalah praduga atau asumsi yang harus diuji melalui data atau fakta yang diperoleh melalui penelitian.

Berdasarkan paradigma penelitiandiatas dan berdasarkan penelitian terdahulu, maka hipotesis dalam penelitian ini sebagai berikut:

H1 :Diduga inflasi berpengaruh terhadap profitabilitas bank.

H2 :Diduga tingkat bagi hasil berpengaruh terhadap profitabilitas bank.

H3 :Diduga tingkat inflasi dan tingkat bagi hasilberpengaruh terhadap profitabilitas bank

\section{HASIL DAN PEMBAHASAN}

\section{Gambaran Objek Penelitian}

\section{Sejarah PT Bank Muamalat Indonesia Tbk}

PT Bank Muamalat Indonesia Tbk (Bank Muamalat Indonesia) memulai perjalanan bisnisnya sebagai Bank Syariah pertama di Indonesia pada 1 November 1991 atau 24 Rabi'us Tsani 1412 H. Pendirian Bank Muamalat Indonesia digagas oleh Majelis Ulama Indonesia (MUI), Ikatan Cendekiawan Muslim Indonesia (ICMI) dan pengusaha muslim yang kemudian mendapat dukungan dari Pemerintah Republik Indonesia. Sejak resmi beroperasi pada 1 Mei 1992 atau 27 Syawal 1412 H, Bank Muamalat Indonesia terus berinovasi dan mengeluarkan produk-produk keuangan syariah seperti Asuransi Syariah (Asuransi Takaful), Dana Pensiun Lembaga Keuangan Muamalat (DPLK Muamalat) dan multifinance syariah (Al-Ijarah Indonesia Finance) yang seluruhnya menjadi terobosan di Indonesia. Selain itu produk Bank yaitu Shar-e yang diluncurkan pada tahun 2004 juga merupakan tabungan instan pertama di Indonesia. Produk Shar-e Gold Debit Visa yang diluncurkan pada tahun 2011 tersebut mendapatkan penghargaan dari Museum Rekor Indonesia (MURI) sebagai Kartu Debit Syariah dengan teknologi chip pertama di Indonesia serta layanan e-channel seperti internet banking, mobile banking, ATM, dan cash management.

Pada 27 Oktober 1994, Bank Muamalat Indonesia mendapatkan izin sebagai Bank Devisa dan terdaftar sebagai perusahaan publik yang tidak listing di Bursa Efek Indonesia (BEI). Seiring kapasitas Bank yang semakin diakui, Bank semakin melebarkan sayap dengan terus menambah jaringan kantor cabangnya di seluruh Indonesia. Pada tahun 2009, Bank mendapatkan izin untuk membuka kantor cabang di Kuala Lumpur, Malaysia dan menjadi bank pertama di Indonesia serta satu-satunya yang mewujudkan ekspansi bisnis di Malaysia. 
Hingga saat ini, Bank telah memiliki 325 kantor layanan termasuk 1 (satu) kantor cabang di Malaysia. Operasional Bank juga didukung oleh jaringan layanan yang luas berupa 710 unit ATM Muamalat, 120.000 jaringan ATM Bersama dan ATM Prima, serta lebih dari 11.000 jaringan ATM di Malaysia melalui Malaysia Electronic Payment (MEPS).

\section{Sejarah PT Bank Rakyat Indonesia (BRI) Syariah Tbk}

Sejarah pendirian PT BRI Syariah Tbk tidak lepas dari akuisisi yang dilakukan PT Bank Rakyat Indonesia (Persero) Tbk terhadap Bank Jasa Arta pada 19 Desember 2007. Setelah mendapatkan izin usaha dari Bank Indonesia melalui surat no. 10/67/Kep.GBI/ DPG/2008 pada 16 Oktober 2008 BRIsyariah resmi beroperasi pada 17 November 2008 dengan nama PT Bank BRIsyariah dan seluruh kegiatan usahanya berdasarkan prinsip syariah Islam.

Pada 19 Desember 2008, Unit Usaha Syariah PT Bank Rakyat Indonesia (Persero) Tbk melebur ke dalam PT Bank BRISyariah. Proses spin off tersebut berlaku efektif pada tanggal 1 Januari 2009 dengan penandatanganan yang dilakukan oleh Sofyan Basir selaku Direktur Utama PT Bank Rakyat Indonesia (Persero) Tbk dan Ventje Rahardjo selaku Direktur Utama PT Bank BRISyariah.

Pada tahun 2018, BRIsyariah mengambil langkah lebih pasti lagi dengan melaksanakan Initial Public Offering pada tanggal 9 Mei 2018 di Bursa Efek Indonesia. IPO ini menjadikan BRIsyariah sebagai anak usaha BUMN di bidang syariah yang pertama melaksanakan penawaran umum saham perdana.

\section{Sejarah PT Bank Bukopin Syariah Tbk}

PT Bank Syariah Bukopin Tbk sebagai bank yang beroperasi dengan prinsip syariah yang bermula masuknya konsorsium PT Bank Bukopin, Tbk diakuisisinya PT Bank Persyarikatan Indonesia (sebuah bank konvensional) oleh PT Bank Bukopin, Tbk., proses akuisisi tersebut berlangsung secara bertahap sejak 2005 hingga 2008, dimana PT Bank Persyarikatan Indonesia yang sebelumnya bernama PT Bank Swansarindo Internasional didirikan di Samarinda, Kalimantan Timur berdasarkan Akta Nomor 102 tanggal 29 Juli 1990 merupakan bank umum yang memperolah Surat Keputusan Menteri Keuangan nomor 1.659/ KMK.013/1990 tanggal 31 Desember 1990 tentang Pemberian Izin Peleburan Usaha 2 (dua) Bank Pasar dan Peningkatan Status Menjadi Bank Umum dengan nama PT Bank Swansarindo Internasional yang memperoleh kegiatan operasi berdasarkan surat Bank Indonesia (BI) nomor 24/1/UPBD/PBD2/Smr tanggal 1 Mei 1991 tentang Pemberian Izin Usaha Bank Umum dan Pemindahan Kantor Bank.

Pada tahun 2001 sampai akhir 2002 proses akuisisi oleh Organisasi Muhammadiyah dan sekaligus perubahan nama PT Bank Swansarindo Internasional menjadi PT Bank Persyarikatan Indonesia yang memperoleh persetujuan dari (BI) nomor 5/4/KEP. DGS/2003 tanggal 24 Januari 2003 yang dituangkan ke dalam akta nomor 109 Tanggal 31 Januari 2003. Dalam perkembangannya kemudian PT Bank Persyarikatan Indonesia melalui tambahan modal dan asistensi oleh PT Bank Bukopin, Tbk., maka pada tahun 2008 setelah memperolah izin kegiatan usaha bank umum yang beroperasi berdasarkan prinsip syariah melalui Surat Keputusan Gubernur Bank Indonesia nomor 10/69/KEP.GBI/DpG/2008 tanggal 27 Oktober 2008 tentang Pemberian Izin Perubahan Kegiatan Usaha Bank Konvensional Menjadi Bank Syariah, dan Perubahan Nama PT Bank Persyarikatan Indonesia Menjadi PT Bank Syariah Bukopin dimana secara resmi mulai efektif beroperasi tanggal 9 Desember 2008, kegiatan operasional Perseroan secara resmi dibuka oleh Bapak M. Jusuf Kalla, Wakil Presiden Republik Indonesia periode 2004 -2009. Sampai dengan akhir Desember 2014 Perseroan memiliki jaringan kantor yaitu 1 (satu) Kantor Pusat dan Operasional, 11 (sebelas) Kantor Cabang, 7 (tujuh) Kantor Cabang Pembantu, 4 (empat) Kantor Kas, 1 (satu) unit mobil kas keliling, dan 76 (tujuh puluh enam) Kantor Layanan Syariah, serta 27 (dua puluh tujuh) mesin ATM BSB dengan jaringan Prima dan ATM Bank Bukopin.
Inflation Rate and Profit Sharing Rate on Sharia Commercial Bank Profitability 
Inflation Rate and

Profit Sharing Rate on

Sharia Commercial

Bank Profitability

\section{Sejarah PT Bank Negara Indonesia (BNI) Syariah Tbk}

Tempaan krisis moneter tahun 1997 membuktikan ketangguhan sistem perbankan syariah. Prinsip Syariah dengan 3 (tiga) pilarnya yaitu adil, transparan dan maslahat mampu menjawab kebutuhan masyarakat terhadap sistem perbankan yang lebih adil. Dengan berlandaskan pada Undang-undang No.10 Tahun 1998, pada tanggal tanggal 29 April 2000 didirikan Unit Usaha Syariah (UUS) BNI dengan 5 kantor cabang di Yogyakarta, Malang, Pekalongan, Jepara dan Banjarmasin. Selanjutnya UUS BNI terus berkembang menjadi 28 Kantor Cabang dan 31 Kantor Cabang Pembantu.

Berdasarkan Keputusan Gubernur Bank Indonesia Nomor 12/41/KEP.GBI/2010 tanggal 21 Mei 2010 mengenai pemberian izin usaha kepada PT Bank BNI Syariah. Dan di dalam Corporate Plan UUS BNI tahun 2003 ditetapkan bahwa status UUS bersifat temporer dan akan dilakukan spin off tahun 2009. Rencana tersebut terlaksana pada tanggal 19 Juni 2010 dengan beroperasinya BNI Syariah sebagai Bank Umum Syariah (BUS). Realisasi waktu spin off bulan Juni 2010 tidak terlepas dari faktor eksternal berupa aspek regulasi yang kondusif yaitu dengan diterbitkannya UU No.19 tahun 2008 tentang Surat Berharga Syariah Negara (SBSN) dan UU No.21 tahun 2008 tentang Perbankan Syariah.

Sejarah PT Bank Central Asia (BCA) Syariah Tbk

Perkembangan perbankan syariah yang tumbuh cukup pesat dalam beberapa tahun terakhir menunjukkan minat masyarakat mengenai ekonomi syariah semakin bertambah. Untuk memenuhi kebutuhan nasabah akan layanan syariah, maka berdasarkan akta Akuisisi No. 72 tanggal 12 Juni 2009 yang dibuat dihadapan Notaris Dr. Irawan Soerodjo, S.H., Msi, .PT.Bank Central Asia, Tbk (BCA) mengakuisisi PT Bank Utama Internasional Bank (Bank UIB) yang nantinya menjadi PT. Bank BCA Syariah.

Selanjutnya berdasarkan Akta Pernyataan Keputusan di Luar Rapat Perseroan Terbatas PT Bank UIB No. 49 yang dibuat dihadapan Notaris Pudji Rezeki Irawati, S.H., tanggal 16 Desember 2009, tentang perubahan kegiatan usaha dan perubahan nama dari PT Bank UIB menjadi PT Bank BCA Syariah. Akta perubahan tersebut telah disahkan oleh Menteri Kehakiman Republik Indonesia dalam Surat Keputusannya No. AHU-01929. AH.01.02 tanggal 14 Januari 2010. Pada tanggal yang sama telah dilakukan penjualan 1 lembar saham ke BCA Finance, sehingga kepemilikan saham sebesar 99,9997\% dimiliki oleh PT Bank Central Asia Tbk, dan 0,0003\% dimiliki oleh PT BCA Finance.

Perubahan kegiatan usaha Bank dari bank konvensional menjadi bank umum syariah dikukuhkan oleh Gubernur Bank Indonesia melalui Keputusan Gubernur BI No. 12/13/KEP.GBI/DpG/2010 tanggal 2 Maret 2010. Dengan memperoleh izin tersebut, pada tanggal 5 April 2010, BCA Syariah resmi beroperasi sebagai bank umum syariah. 
Analisis Tingkat Inflasi karena merupakan data Nasional, sehingga dianalisa tidak pada masing-masing bank. Berdasarkan data inflasi bulanan yang penulis peroleh melalu website Bank Indonesia(BI) dirata-ratakan menjadi pertahun, berikut ini adalah tabel analisis deskriptif tingkat inflasi diantaranya rata-rata, standardeviasi, nilai minimum dan nilai maksimum.

Tabel 5. Deskriptif Inflasi

\begin{tabular}{|c|c|}
\hline Tahun & Tingkat Inflasi (\%) \\
\hline 2011 & 6,38 \\
\hline 2012 & 3,53 \\
\hline 2013 & 3,81 \\
\hline 2014 & 6,42 \\
\hline 2015 & 5,38 \\
\hline 2016 & 4,28 \\
\hline 2017 & 6,97 \\
\hline 2018 & 3,20 \\
\hline Rata-rata & 4,996 \\
\hline StandarDeviasi & 1,478 \\
\hline Minimum & 3,200 \\
\hline Maksimum & 6,970 \\
\hline
\end{tabular}

(Sumber: Data Inflasi Bank Indonesia (Data Diolah))

Hasil pada tabel deskriptif menunjukkan nilai rata-rata inflasi sebesar 4,996 dengan standar deviasi 1,478. Nilai minimum sebesar 3,200 dan nilai maksimum sebesar 6,970. Hasil rata-rata lebih besar dari standardeviasi, artinya sebaran data Tingkat Inflasi masih relatif homogen. Berikut ini adalah grafik pertumbuhan Tingkat Inflasi periode 2011-2018:

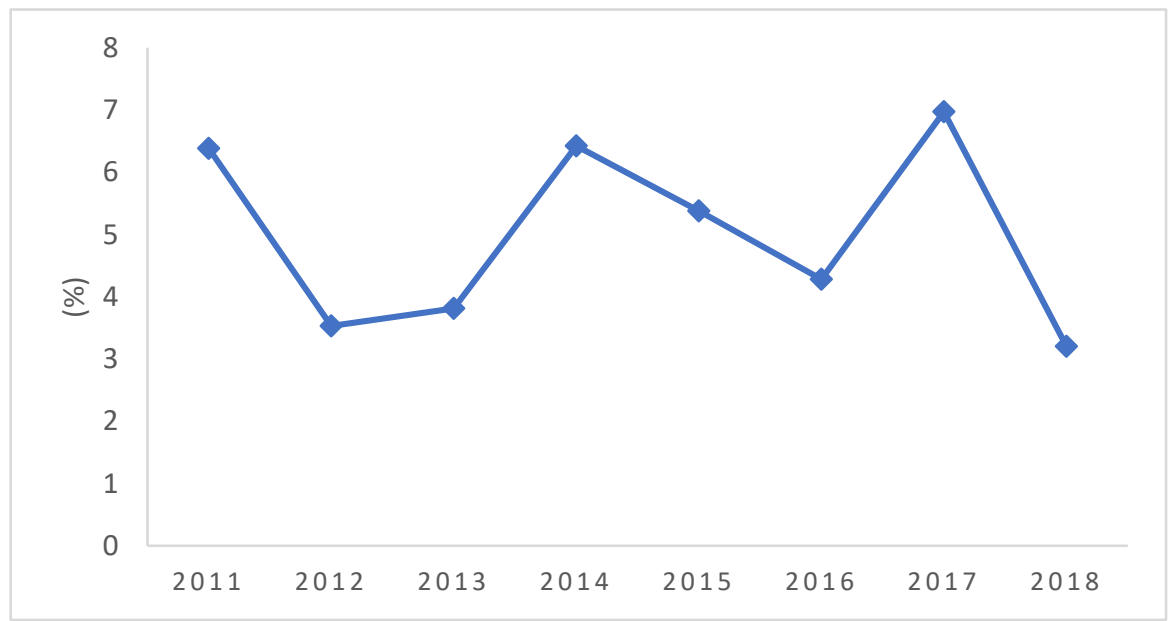

Gambar 3. Grafik Tingkat Inflasi Periode 2011 - 2018 
Inflation Rate and Profit Sharing Rate on Sharia Commercial Bank Profitability
Analisis Tingkat Bagi Hasil dan Return on Asset (ROA) PT Bank Muamalat Indonesia, Tbk Tabel 6. Deskriptif Tingkat Bagi Hasil dan ROA PT Bank Muamalat Indonesia, Tbk

\begin{tabular}{|c|c|c|}
\hline Tahun & Tingkat Bagi Hasil (\%) & ROA (\%) \\
\hline 2011 & 11,55 & 1,52 \\
\hline 2012 & 10,81 & 1,54 \\
\hline 2013 & 10,19 & 1,37 \\
\hline 2014 & 9,95 & 0,17 \\
\hline 2015 & 8,66 & 0,20 \\
\hline 2016 & 8,05 & 0,22 \\
\hline 2017 & 8,93 & 0,11 \\
\hline 2018 & 9,69 & 0,80 \\
\hline Rata-rata & 9,729 & 0,741 \\
\hline Standar Deviasi & 1,156 & 0,647 \\
\hline Minimum & 8,050 & 0,110 \\
\hline Maksimum & 11,550 & 1,540 \\
\hline
\end{tabular}

(Sumber: Annual Report PT Bank Muamalat Indoenesia, Tbk (Data Diolah))

Hasil pada tabel deskriptif menunjukkan nilai rata-rata Tingkat Bagi Hasil sebesar 9,729 dengan standar deviasi 1,156. Nilai minimum sebesar 8,050 dan nilai maksimum sebesar 11,550. Hasil rata-rata lebih besar dari standar deviasi, artinya sebaran data Tingkat Bagi Hasil masih relatif homogen. Nilai rata-rata ROA sebesar 0,741 dengan standar deviasi 0,647 . Nilai minimum sebesar 0,110 dan nilai maksimum sebesar 1,540 . Hasil rata-rata lebih besar dari standar deviasi, artinya sebaran data ROA masih relatif homogen. Berikut ini adalah grafik pertumbuhan Tingkat Bagi Hasil dan ROA PT Bank Muamalat Indonesia, Tbk periode 2011-2018:

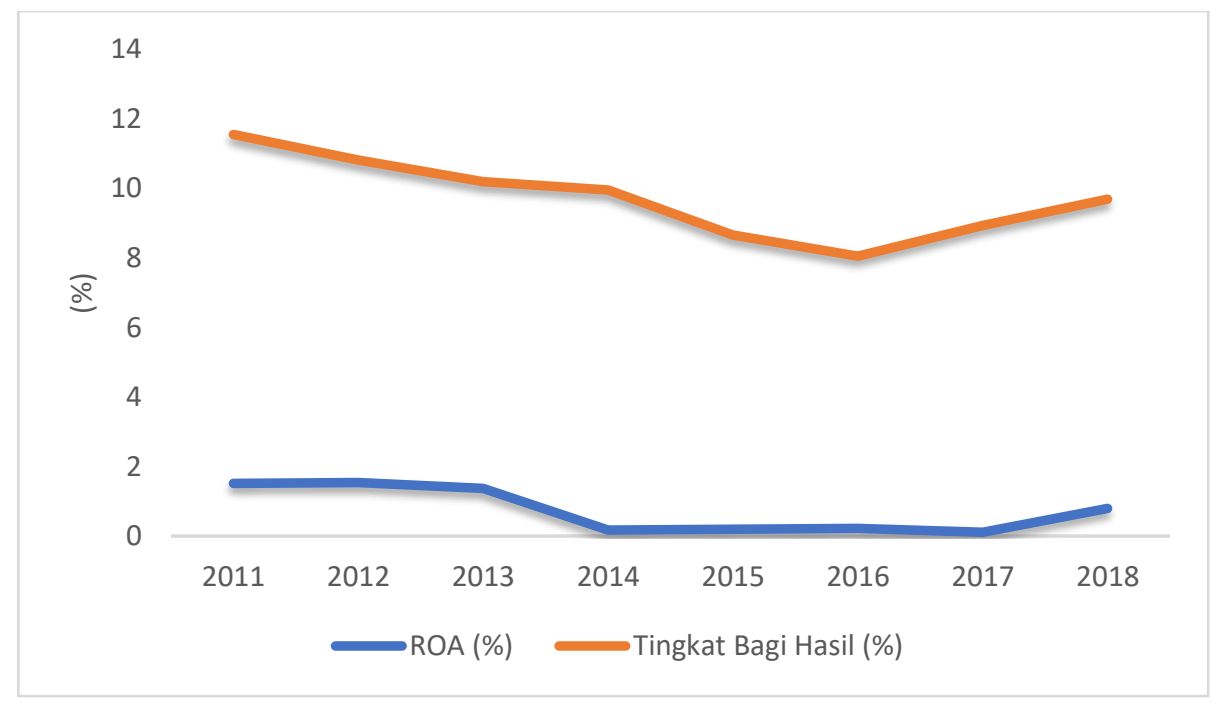

Gambar 4. Grafik Pergerakan Data Tingkat Bagi Hasil dan ROA PT Bank Muamalat Indonesia, Tbk Periode 2011-2018 
Analisis Tingkat Bagi Hasil dan Return on Asset (ROA) PT Bank Rakyat Indonesia (BRI) Syariah, Tbk

Tabel 7. Deskriptif Tingkat Bagi Hasil dan ROA PT Bank Rakyat Indonesia (BRI) Syariah, Tbk

\begin{tabular}{|c|c|c|}
\hline Tahun & Tingkat Bagi Hasil (\%) & ROA (\%) \\
\hline 2011 & 9,92 & 0,2 \\
\hline 2012 & 10,28 & 1,19 \\
\hline 2013 & 10,08 & 1,15 \\
\hline 2014 & 9,32 & 0,08 \\
\hline 2015 & 10,74 & 0,77 \\
\hline 2016 & 10,58 & 0,95 \\
\hline 2017 & 10,66 & 0,51 \\
\hline 2018 & 9,19 & 0,43 \\
\hline Rata-rata & 10,096 & 0,660 \\
\hline StandarDeviasi & 0,592 & 0,421 \\
\hline Minimum & 9,190 & 0,080 \\
\hline Maksimum & 10,740 & 1,190 \\
\hline
\end{tabular}

(Sumber: Annual Report PT Bank Rakyat Indoenesia (BRI) Syariah, Tbk (Data Diolah))

Hasil pada tabel deskriptif menunjukkan nilai rata-rata Tingkat Bagi Hasil sebesar 10,096 dengan standar deviasi 0,592. Nilai minimum sebesar 9,190 dan nilai maksimum sebesar 10,740. Hasil rata-rata lebih besar dari standar deviasi, artinya sebaran data Tingkat Bagi Hasil masih relatif homogen. Nilai rata-rata ROA sebesar 0,660 dengan standar deviasi 0,421 . Nilai minimum sebesar 0,080 dan nilai maksimum sebesar 1,190 . Hasil rata-rata lebih besar dari standar deviasi, artinya sebaran data ROA masih relatif homogen. Berikut adalah grafik pertumbuhan Tingkat Bagi Hasil dan ROA PT Bank Rakyat Indonesia (BRI) Syariah, Tbk periode 2011-2018:

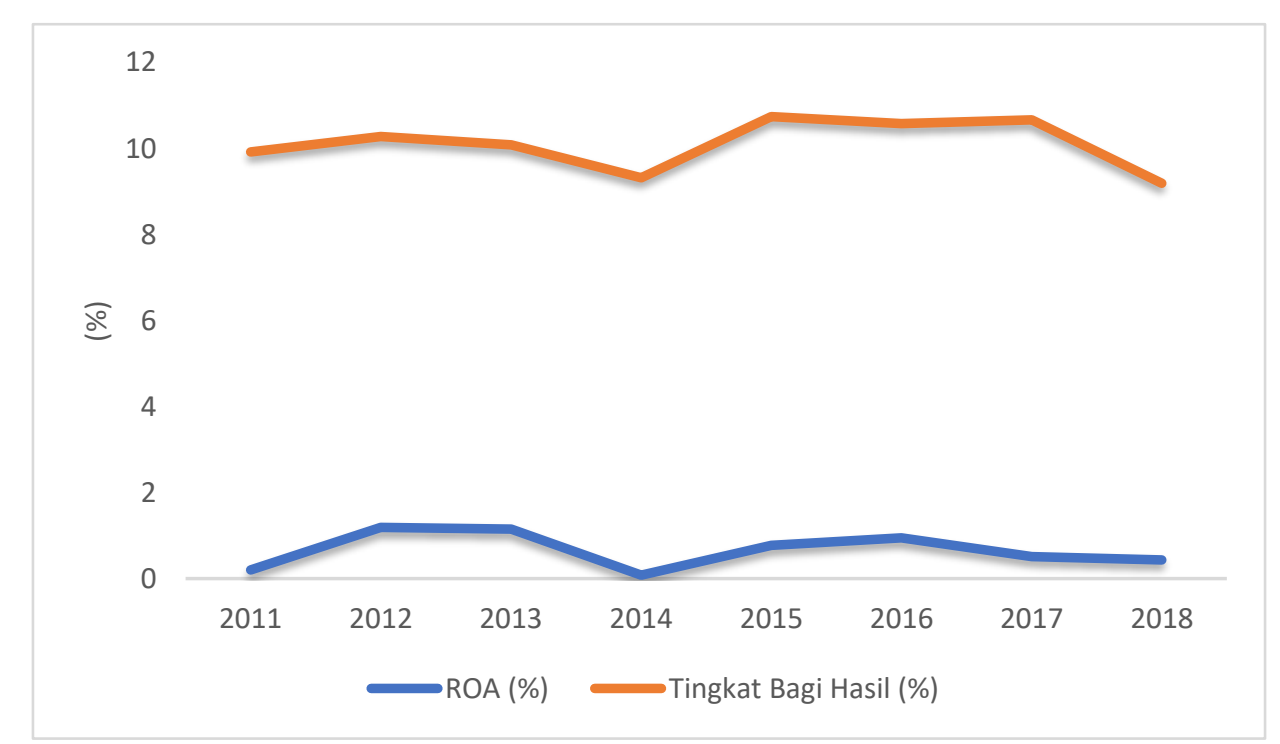

\section{Gambar 5. GrafikPergerakan Data Tingkat Bagi Hasil dan ROA PT Bank Rakyat Indonesia (BRI) Syariah, Tbk Periode 2011-2018}

Inflation Rate and Profit Sharing Rate on Sharia Commercial Bank Profitability 
Inflation Rate and Profit Sharing Rate on Sharia Commercial Bank Profitability 
Analisis Tingkat Bagi Hasil dan Return on Asset (ROA) PT Bank Negara Indonesia (BNI) Syariah, Tbk

Tabel 9. Deskriptif Tingkat Bagi Hasil dan ROA PT Bank Negara Indonesia (BNI) Syariah, Tbk

\begin{tabular}{|c|c|c|}
\hline Tahun & Tingkat Bagi Hasil (\%) & ROA (\%) \\
\hline 2011 & 10,62 & 1,29 \\
\hline 2012 & 9,79 & 1,48 \\
\hline 2013 & 9,74 & 1,37 \\
\hline 2014 & 9,72 & 1,27 \\
\hline 2015 & 9,18 & 1,43 \\
\hline 2016 & 10,24 & 1,44 \\
\hline 2017 & 8,94 & 1,31 \\
\hline 2018 & 7,74 & 1,42 \\
\hline Rata-rata & 9,496 & 1,376 \\
\hline StandarDeviasi & 0,887 & 0,078 \\
\hline Minimum & 7,740 & 1,270 \\
\hline Maksimum & 10,620 & 1,480 \\
\hline
\end{tabular}

(Sumber: Annual Report PT Bank Negara Indonesia (BNI) Syariah, Tbk (Data Diolah))

Hasil pada tabel deskriptif menunjukkan nilai rata-rata Tingkat Bagi Hasil sebesar 9,496 dengan standar deviasi 0,887 . Nilai minimum sebesar 7,740 dan nilai maksimum sebesar 10,620. Hasil rata-rata lebih besar dari standar deviasi, artinya sebaran data Tingkat Bagi Hasil masih relatif homogen. Nilai rata-rata ROA sebesar 1,376 dengan standar deviasi 0,078 . Nilai minimum sebesar 1,270 dan nilai maksimum sebesar 1,480. Hasil rata-rata lebih besar dari standar deviasi, artinya sebaran data ROA masih relatif homogen. Berikut adalah grafik pertumbuhan Tingkat Bagi Hasil dan ROA PT Bank Negara Indonesia (BNI) Syariah, Tbk periode 2011-2018:

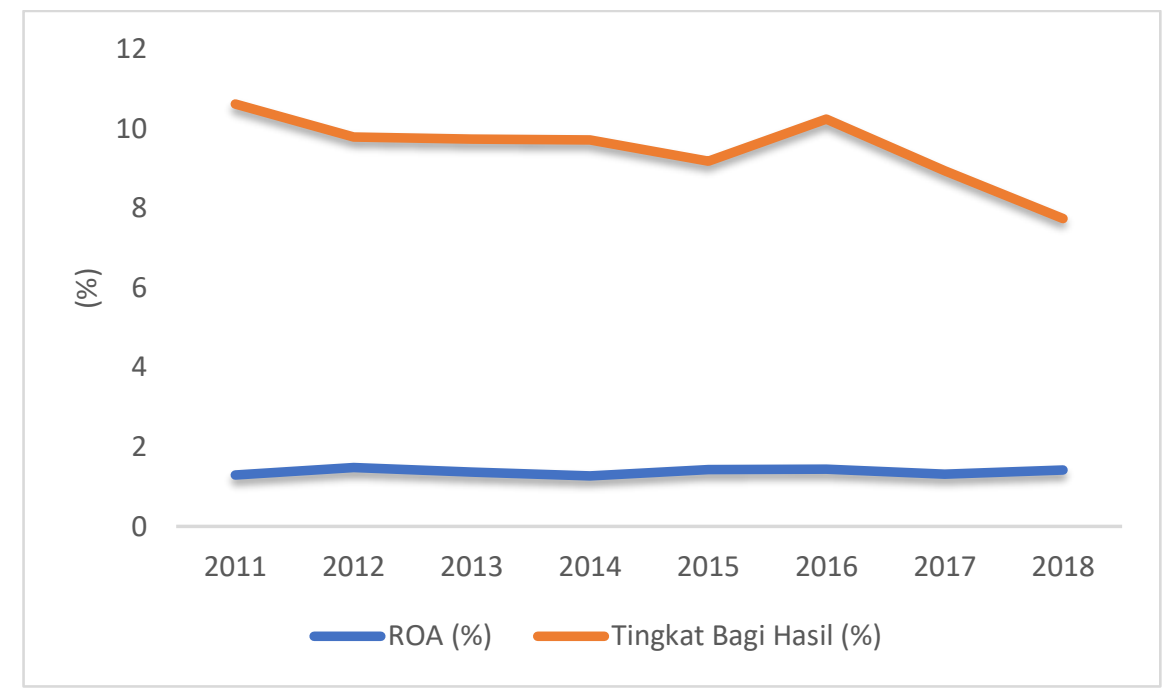

Gambar 7. GrafikPergerakan Data Tingkat Bagi Hasil dan ROA PT Bank Negara Indonesia (BNI) Syariah, Tbk Periode 2011-2018
Inflation Rate and Profit Sharing Rate on Sharia Commercial Bank Profitability 
Inflation Rate and Profit Sharing Rate on Sharia Commercial Bank Profitability
Analisis Tingkat Bagi Hasil dan Return on Asset (ROA)PT Bank Central Asia (BCA) Syariah, Tbk

Tabel 10. Deskriptif Tingkat Bagi Hasil dan ROA PT Bank Central Asia (BCA) Syariah, Tbk

\begin{tabular}{|c|c|c|}
\hline Tahun & Tingkat Bagi Hasil (\%) & ROA (\%) \\
\hline 2011 & 6,43 & 0,90 \\
\hline 2012 & 6,83 & 0,80 \\
\hline 2013 & 8,72 & 1,00 \\
\hline 2014 & 8,83 & 0,80 \\
\hline 2015 & 10,92 & 1,00 \\
\hline 2016 & 9,39 & 1,10 \\
\hline 2017 & 9,33 & 1,20 \\
\hline 2018 & 9,34 & 1,20 \\
\hline Rata-rata & 8,724 & 1,000 \\
\hline StandarDeviasi & 1,458 & 0,160 \\
\hline Minimum & 6,430 & 0,800 \\
\hline Maksimum & 10,920 & 1,200 \\
\hline
\end{tabular}

(Sumber: Annual Report PT Bank Central Asia (BCA) Syariah, Tbk(Data Diolah))

Hasil pada tabel deskriptif menunjukkan nilai rata-rata Tingkat Bagi Hasil sebesar 8,724 dengan standar deviasi 1,458. Nilai minimum sebesar 6,430 dan nilai maksimum sebesar 10,920. Hasil rata-rata lebih, artinya sebaran data Tingkat Bagi Hasil masih relatif homogen. Nilai rata-rata ROA sebesar 1,000 dengan standar deviasi 0,160. Nilai minimum sebesar 0,800 dan nilai maksimum sebesar 1,200. Hasil rata-rata lebih besar dari standar deviasi, artinya sebaran data ROA masih relatif homogen. Berikut adalah grafik pertumbuhan Tingkat Bagi Hasil dan ROA PT Bank Central (BCA) Syariah, Tbk periode 2011-2018:

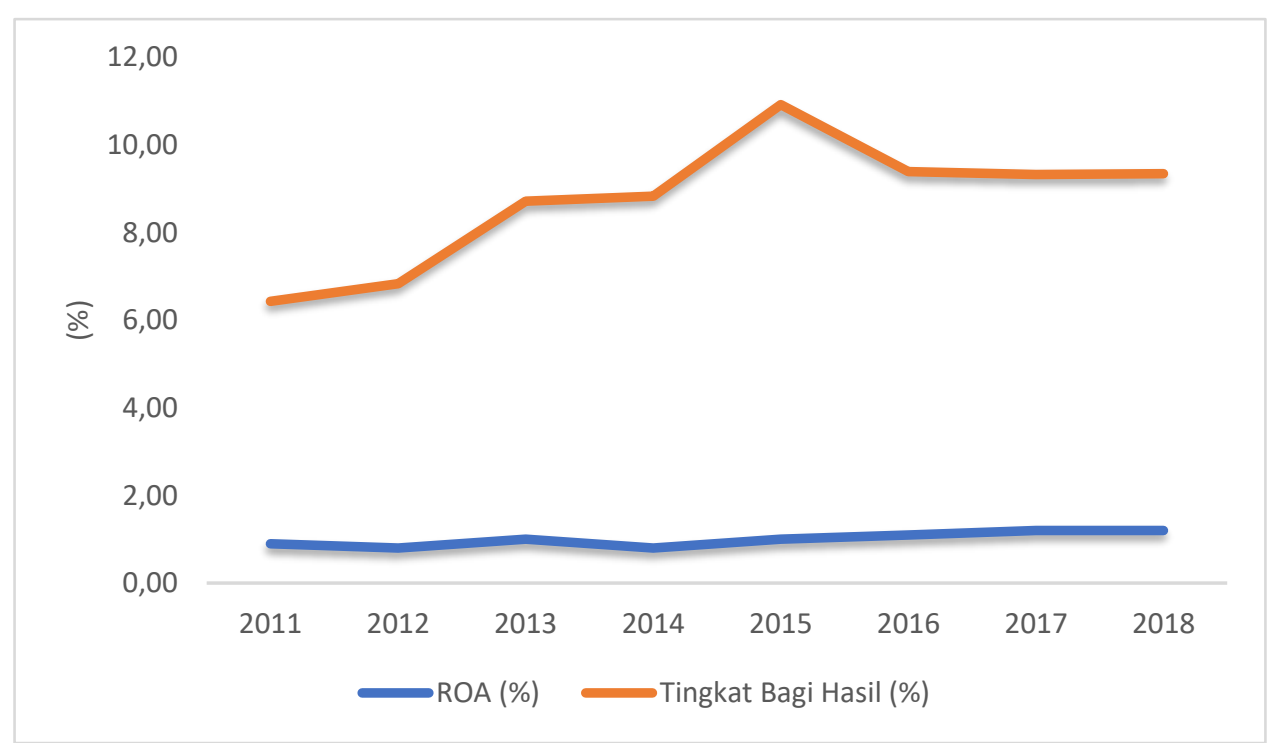

Gambar 8. GrafikPergerakan Data Tingkat Bagi Hasil dan ROA PT Bank Central Asia (BCA) Syariah, Tbk Periode 2011-2018 


\section{Hasil Analisis Regresi Data Panel}

Hasil estimasi model regresi panel terdiriatas model Pooled Least Square (PLS) atau Common Effect Model (CEM), model Fixed Effect Model (FEM) dan Random Effect Model (REM). Dari ketiga model tersebut akan ditentukan model terbaik berdasarkan indikator model terbaik, dan uji perbandingan model. Berikut adalah tabel hasil perbandingan tiga model:

Tabel 11. Hasil Estimasi Model Regresi Data Panel

\begin{tabular}{|l|c|l|c|c|c|c|}
\hline \multirow{2}{*}{ Variable } & \multicolumn{2}{|c|}{ PLS } & \multicolumn{2}{c|}{ FEM } & \multicolumn{2}{c|}{ REM } \\
\cline { 2 - 7 } & Coefficient & Prob. & Coefficient & Prob. & Coefficient & Prob. \\
\hline Tingkat Inflasi & $-0,0892$ & 0,1186 & $-0,0817$ & $0,0012^{* *}$ & $-0,0965$ & $0,0061^{* *}$ \\
\hline $\begin{array}{c}\text { Tingkat Bagi } \\
\text { Hasil }\end{array}$ & 0,0034 & 0,9578 & 0,1644 & $0,0000^{* *}$ & 0,1755 & $0,0000^{* *}$ \\
\hline C & 1,2485 & 0,0732 & $-0,3701$ & 0,0511 & $-0,4059$ & 0,0895 \\
\hline R-squared & 0.064557 & \multicolumn{2}{c|}{0,772594} & 0,319525 \\
\hline $\begin{array}{l}\text { Adjusted R- } \\
\text { squared }\end{array}$ & 0,013992 & \multicolumn{2}{c|}{0,731247} & 0,282742 \\
\hline $\begin{array}{l}\text { S.E. of } \\
\text { regression }\end{array}$ & 0,487641 & 0,283332 & 0,320429 \\
\hline F-statistic & 1,276718 & 18,685810 & 8,686883 \\
\hline $\begin{array}{l}\text { Prob(F- } \\
\text { statistic) }\end{array}$ & 0,290954 & 0,000000 & 0,000807 \\
\hline $\begin{array}{l}\text { Durbin- } \\
\text { Watson stat }\end{array}$ & 0,528079 & 1,942724 & 0,968275 \\
\hline
\end{tabular}

Keterangan : **) Significant at level 5\%

Berdasarkan tabel perbandingan hasil ketiga model Pooled Least Square (PLS)/ Common Effect Model (CEM), Fixed Effect Model (FEM) dan Random Effect Model (REM), maka dapat disimpulkan bahwa model terbaik adalah Fixed Effect Model (FEM). Hal tersebut didukung oleh indikator kebaikan model yaitu nilai R-squared sebesar 77,26 \% lebih tinggi dibandingkan dengan R-squared model Pooled Least Square (PLS) danRandom Effect Model (REM). Selain nilai R-squared tertinggi, Fixed Effect Model (FEM) memiliki tingkat signifikansi dari masing-masing variabel independen, karena kedua variabel independenya itu Tingkat Inflasi dan Tingkat Bagi Hasil memiliki nilai probabilitas yang lebih kecil dari alpha $5 \%$. Hal tersebut tidak dimiliki oleh model Pooled Least Square (PLS) dan Random Effect Model(REM).

\section{Hasil Uji Perbandingan Model Terbaik}

Untuk menguji atau memilih model terbaik, maka uji yang digunakan adalah Uji Hausman dan Uji Chow. Berikut adalah tabel uji perbandingan model :
Inflation Rate and Profit Sharing Rate on Sharia Commercial Bank Profitability 
Inflation Rate and Profit Sharing Rate on Sharia Commercial Bank Profitability
Tabel 12. Hasil Uji Perbandingan Model

\begin{tabular}{|c|c|c|c|c|c|}
\hline Uji & Hipotesis & $\begin{array}{c}\text { Chi-Sq. } \\
\text { Statistic }\end{array}$ & $\begin{array}{c}\text { Chi-Sq. } \\
\text { d.f. }\end{array}$ & Prob. & Kesimpulan \\
\hline Hausman & $\begin{array}{l}\text { H0 : REM } \\
\text { H1 : FEM }\end{array}$ & 9,272314 & 2 & 0,0097 & FEM \\
\hline Chow & $\begin{array}{l}\text { H0 : PLS } \\
\text { H1 : FEM }\end{array}$ & 25,375548 & $(4,33)$ & 0,0000 & FEM \\
\hline
\end{tabular}

H0 : Random Effect Model (REM)

H1 : Fixed Effect Model (FEM)

Hasil uji Hausman menunjukkan nilai prob. $0,0097<0,005$ artinya model terpilih adalah Fixed Effect Model (FEM). Hasil uji Chow menunjukkan nilai prob. $0,0000<0,005$ artinya model terpilih adalah Fixed Effect Model (FEM).

Berdasarkan keputusan perbandingan model terbaik, baik dari sisi kebaikan indikator model maupun uji beda perbandingan antar model. Maka peneliti memutuskan bahwa model terbaik adalah Fixed Effect Model (FEM).

\section{Interpretasi Model Terbaik}

Analisis ini merupakan hasil pengolahan data dengan menggunakan Eviews 9.0 yang mengujipengaruh tingkat inflasi, tingkat bagi hasil terhadap Return On Asset (ROA). Berikut data yang diolah:

Tabel 13. Coefficient Tingkat Inflasi, Tingkat Bagi Hasil Terhadap ROA

\begin{tabular}{|l|c|c|c|c|c|}
\hline \multicolumn{1}{|c|}{ Variable } & Coefficient & Std. Error & t-Stat. & Prob. & VIF \\
\hline Tingkat Inflasi & $-0,0817$ & 0,0231 & $-3,5431$ & 0,0012 & 1,0 \\
\hline Tingkat Bagi Hasil & 0,1644 & 0,0253 & 6,4985 & 0,0000 & 1,0 \\
\hline C & $-0,3701$ & 0,1828 & $-2,0246$ & 0,0511 & \\
\hline & & & & & \\
\hline R-squared & 0,7726 & \multicolumn{2}{|l|}{ Mean dependent var } & 0,94351 & \\
\hline Adjusted R-squared & 0,7312 & \multicolumn{2}{|l|}{ S.D. dependent var } & 0,65879 & \\
\hline S.E. of regression & 0,2833 & \multicolumn{2}{l|}{ Sum squared resid } & 2,64913 & \\
\hline F-statistic & 18,6858 & Durbin-Watson stat & 1,94272 & \\
\hline Prob(F-statistic) & 0,0000 & & & \\
\hline
\end{tabular}

(Sumber :Eviews 2020 (Data Diolah))

Berdasarkan tabel diatas dapat diperoleh persamaan regresi sebagai berikut :

ROA $=-0,3701-0,0817$ Tingkat Inflasi+ 0,1644Tingkat Bagi Hasil

Hasil pada tabel 4.9 menunjukkan pengaruh Tingkat Inflasi signifikan dan negatif terhadap ROA, dengan nilai probabilitas 0,0012. Nilai probabilitas 0,0012 lebih kecil dari alpha 5\%. Koefisien regresi sebesar -0,0817 artinya jika Tingkat Inflasi naik sebesar 1\% maka ROA akan turun sebesar $8,17 \%$ dengan asumsi variabel lain dianggap constant.

Tingkat Bagi Hasil signifikan dan positif terhadap ROA, dengan nilai probabilitas 0,0000. Nilai probabilitas 0,0000 lebih kecil dari alpha 5\%. Koefisien regresi sebesar 0,1644 artinya jika Tingkat Bagi Hasil naik sebesar 1\% maka ROA akan naik sebesar 16,44\% dengan asumsi variabel lain dianggap constant.

Hasil uji $\mathrm{F}$ menunjukkan nilai $\mathrm{F}$ hitung sebesar 18,6858 dengan nilai probabilitas 0,000000 , karena nilai probabilitas lebih kecil dari alpha $5 \%$, artinya secara bersama-sama Tingkat Inflasi dan Tingkat Bagi Hasil berpengaruh signifikan terhadap ROA.

Nilai koefisien determinasi ( $R$-square) sebesar 0,7726 atau 77,26\%, artinya bahwa variabel kontribusi pengaruh Tingkat Inflasi dan Tingkat Bagi Hasil terhadap ROA sebesar 77,26\% sedangkan sisanya sebesar 22,74\% ditentukan oleh faktor lain yang tidak diteliti. 


\section{Hasil Uji Asumsi Klasik}

Uji Asumsi klasik meliputi Uji Asumsi Kenormalan Residual (Error Model), Uji Multikolinearitas, Uji Homoskedastisitas, dan Uji Autokorelasi. Berikut adalah hasil uji asumsi klasik untuk model terbaik Fixed Effect Model (FEM).

\section{Uji Kenormalan Residual}

Pada uji asumsi kenormalan residual ini diuji menggunakan uji Jarque-Bera.

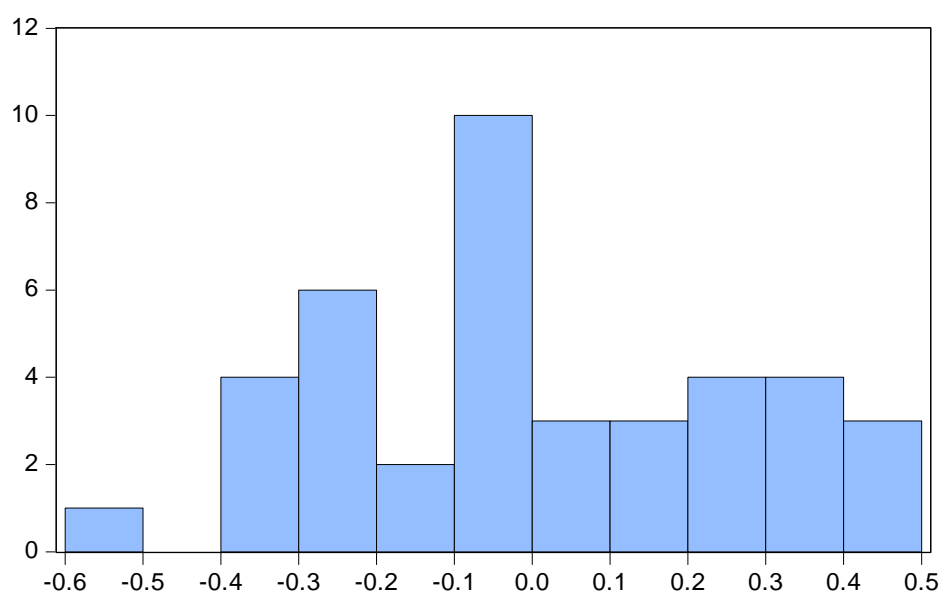

Series: Standardized Residuals Sample 20112018

Observations 40

Mean $\quad 1.53 \mathrm{e}-17$

Median $\quad-0.052750$

Maximum $\quad 0.429360$

Minimum $\quad-0.588372$

Std. Dev. $\quad 0.260627$

Skewness $\quad 0.039815$

Kurtosis $\quad 2.138585$

Jarque-Bera 1.247295

Probability $\quad 0.535986$

\section{Gambar 9. Diagram Uji Kenormalan Residual}

H0 : Residual menyebar normal

H1 : Residual tidakmenyebar normal

Hasil prob. 0,535986>0,05 maka terima H0 artinya asumsi residual menyebar secara normal telah terpenuhi.

\section{Uji Homoskedastisitas}

Berikut ini adalah tabel hasil Uji Homoskedastisitas.

Tabel 14. Uji Homoskedastisitas

\begin{tabular}{llrl}
\hline \hline \multicolumn{1}{c}{ Test } & Statistic & d.f. & Prob. \\
\hline \hline Breusch-Pagan LM & 8.495901 & 10 & 0.5805 \\
Pesaran scaled LM & -1.454361 & & 0.1458 \\
Bias-corrected scaled LM & -1.811504 & & 0.0701 \\
Pesaran CD & -1.029674 & & 0.3032 \\
\hline \hline
\end{tabular}

H0 :Homoskedastisitas

$\mathrm{H} 1$ :Heteroskedastisitas

Nilai prob. Breusch-Pagan LM0.5805 >0.05, artinya asumsi homoskedastisitas telah terpenuhi.

\section{Uji Multikolinearitas}

Hasil Variance Inflation Factor (VIF) pada tabel 4.9 menunjukkan nilai sebesar 1,0, karena nilai Variance Inflation Factor VIF 1,0 lebih rendah dari 10 artinya asumsi bebas multikolinieritas telah terpenuhi. 
Inflation Rate and

Profit Sharing Rate on

Sharia Commercial

Bank Profitability
Uji Autokorelasi

Berdasarkan Durbin-Watsontable diperoleh nilai DL=1,3635, DU =1,5904,4-DU=2,4096 dan 4-DL $=2,6365$. Hasil model Fixed Effect Model (FEM) menunjukkan nilai DW sebesar 1,94272, karena nilai DU $<$ DW $<4$-DU artinya sudah bebas dari autokorelasi.

Koefisien Determinasi $\left(\mathbf{R}^{2}\right)$

Nilai koefisien determinasi ( $R$-square) pada Tingkat Inflasi dan Tingkat Bagi Hasil terhadap Return on Assets (ROA) sebesar 0,7726 atau 77,26\%, artinya bahwa variabel independenTingkat Inflasi dan Tingkat Bagi Hasil mampu menjelaskan keragaman dari variabel Return On Asset (ROA) sebesar 77,26\% dan sisanya 22,74 \% ditentukan oleh faktor lain yang tidak teliti.

\section{Pembahasan Penelitian}

Berdasarkan data penelitian yang dilakukan, peneliti akan melanjutkan pembahasan lebih mendalam dan menjelaskan makna dari setiap masing-masing output pengolah data yang relevan, serta menguraikan dengan mendalam dan mengaitkan dengan keilmuan atau teori yang ada.

\section{Pengaruh Tingkat Inflasi Terhadap Return on Asset (ROA)}

Dari penelitian secara parsial variabel Tingkat Inflasi berpengaruh negatif dan signifikan terhadap Return on Asset (ROA) dan diperoleh signifikan sebesar 0,0012 yang berarti bahwa tingkat signifikansi Tingkat Inflasi lebih kecil dari 0,05.

Inflasi adalah terjadinya kenaikan harga-harga barang dan jasa secara keseluruhan dalam perekonomian suatu negara pada periode waktu tertentu. Inflasi yang tinggi menyebabkan berkurangnya profitabilitas bank syariah dikarenakan terjadinya kredit atau pembiayaan macet dan berkurangnya masyarakat yang menabung karena mereka lebih memilih untuk menggunakan dananya memenuhi kebutuhan pokok yang sedang naik.

Berdasarkan hasil dari penelitian dapat disimpulkan bahwa variabel Tingkat Inflasi terhadap Return on Asset (ROA) PT Bank Muamalat Indonesia Tbk, PT BRI Syariah Tbk, PT Bank Bukopin Syariah Tbk, PT BNI Syariah Tbk, dan PT BCA Syariah memiliki pengaruh yang signifikan dan negatif. Hal ini menunjukkan jika Tingkat Inflasi semakin tinggi maka pendapatan atau profit akan menurun. Hal ini di dukung oleh teori inflasi yang dikemukakan oleh Weston dan Copeland (1995: 17), inflasi yang semakin tinggi maka membuat nilai riil tabungan merosot karena masyarakat akan mengurangi nilai kekayaan yang berbentuk uang, simpanan di bank, simpanan tunai, serta mempergunakan hartanya untuk mencukupi biaya pengeluaran akibat naiknya harga-harga barang sehingga akan mempengaruhi kinerja dan profitabilitas bank (R Gustiono, 2017).

Hasil penelitian ini sejalan dengan penelitian terdahulu yang dilakukan oleh R. Gustiono (2017), Duraj dan Moci (2015), dimana Tingkat Inflasi berpengaruh negatif dan signifikan terhadap Return on Asset (ROA). Namun penelitian ini bertolak belakang dengan penelitian yang dilakukan oleh Arifin (2016) bahwa variabel Tingkat Inflasi berpengaruh positif signifikan terhadapReturn on Asset (ROA), dan penelitian yang dilakukan oleh Umrotul, Irsad,dan Haerudin (2017), Bastari (2015), serta Ainur (2019) bahwa Tingkat Inflasi tidak berpengaruh terhadap Return on Asset (ROA).

\section{Pengaruh Tingkat Bagi Hasil Terhadap Return on Asset (ROA)}

Dari penelitian secara parsial variabel Tingkat Bagi Hasil berpengaruh positif dan signifikan terhadap Return on Asset (ROA) dan diperoleh signifikan sebesar 0,0000 yang berarti bahwa tingkat signifikansi Tingkat Bagi Hasil lebih kecil dari 0,05.

Bagi Hasil adalah bentuk return (perolehan kembali) dari kontrak investasi, dari waktu ke waktu, tidak pasti dan tidak tetap. Besar-kecilnya perolehan kembali itu bergantung pada hasil usaha yang benar-benar terjadi.Nilai nominal bagi hasil yang nyata diterima, dapat diketahui setelah hasil pemanfaatan dana tersebut benar-benar telah ada. 
Berdasarkan hasil dari penelitian dapat disimpulkan bahwa variabel Tingkat Bagi Hasil terhadap Return on Asset (ROA) PT Bank Muamalat Indonesia Tbk, PT BRI Syariah Tbk, PT Bank Bukopin Syariah Tbk, Pt BNI Syariah Tbk, dan PT BCA Syariah memiliki pengaruh yang signifikan dan positif, artinya semakin tinggi pendapatan bagi hasil, maka profitabilitas bank syariah akan naik dan jika pendapatan bagi hasil turun, maka profitabilitas bank syariah menurun. Hal ini dikarenakan pendapatan yang diperoleh akan mempengaruhi besarnya laba yang diperoleh bank. Besarnya laba yang diperoleh bank syariah akan mampu mempengaruhi profitabilitas yang dicapai.

Hasil penelitian ini sejalan dengan penelitian terdahulu yang dilakukan oleh N. Nadliroh (2013), Kusumah (2013), dimana Tingkat Bagi Hasil berpengaruh positif dan signifikan terhadap Return on Asset (ROA). Namun penelitian ini bertolak belakang dengan penelitian yang dilakukan oleh Slamet (2014) dan RK Devi (2018) bahwa variabel Tingkat Bagi Hasil berpengaruh negatif signifikan terhadapReturn on Asset (ROA), dan penelitian yang dilakukan oleh Bastari (2015) dan Ainur (2019) bahwa Tingkat Bagi Hasil tidak berpengaruh terhadap Return on Asset (ROA).

Pengaruh Tingkat Inflasi dan Tingkat Bagi Hasil Terhadap Return on Asset (ROA)

Dari penelitian secara simultan variabel Tingkat Inflasi dan Tingkat Bagi Hasil terhadap Return on Asset (ROA) berpengaruh signifikan terhadap Return on Assets (ROA). Diperoleh nilai probabilitas $(0.000000)$, karena nilai probabilitas lebih kecil dari alpha $5 \%$, artinya secara bersama-sama Tingkat Inflasi dan Tingkat Bagi Hasil berpengaruh signifikan.

\section{Hasil Pengujian Hipotesis}

Tabel 15. Hasil Pengujian Hipotesis

\begin{tabular}{|l|c|c|c|c|c|}
\hline No & Hipotesis & $\begin{array}{c}\text { T Tabel } \\
\mathrm{t} / \mathrm{f}\end{array}$ & $\begin{array}{c}\text { Significance } \\
(0,05)\end{array}$ & Coefficients & $\begin{array}{c}\text { Hasil } \\
\text { Hipotesis }\end{array}$ \\
\hline 1 & Tingkat Inflasi $\rightarrow$ ROA & $-3,5431$ & 0,0012 & $-0,0817$ & Diterima \\
\hline 2 & $\begin{array}{l}\text { Tingkat Bagi Hasil } \rightarrow \\
\text { ROA }\end{array}$ & 6,4985 & 0,0000 & 0,1644 & Diterima \\
\hline 3 & $\begin{array}{c}\text { Tingkat Inflasi dan } \\
\text { Tingkat Bagi Hasil } \rightarrow \\
\text { ROA }\end{array}$ & 18,6858 & 0,0000 & Diterima \\
\hline
\end{tabular}

Inflation Rate and Profit Sharing Rate on Sharia Commercial Bank Profitability 
Inflation Rate and Profit Sharing Rate on Sharia Commercial Bank Profitability

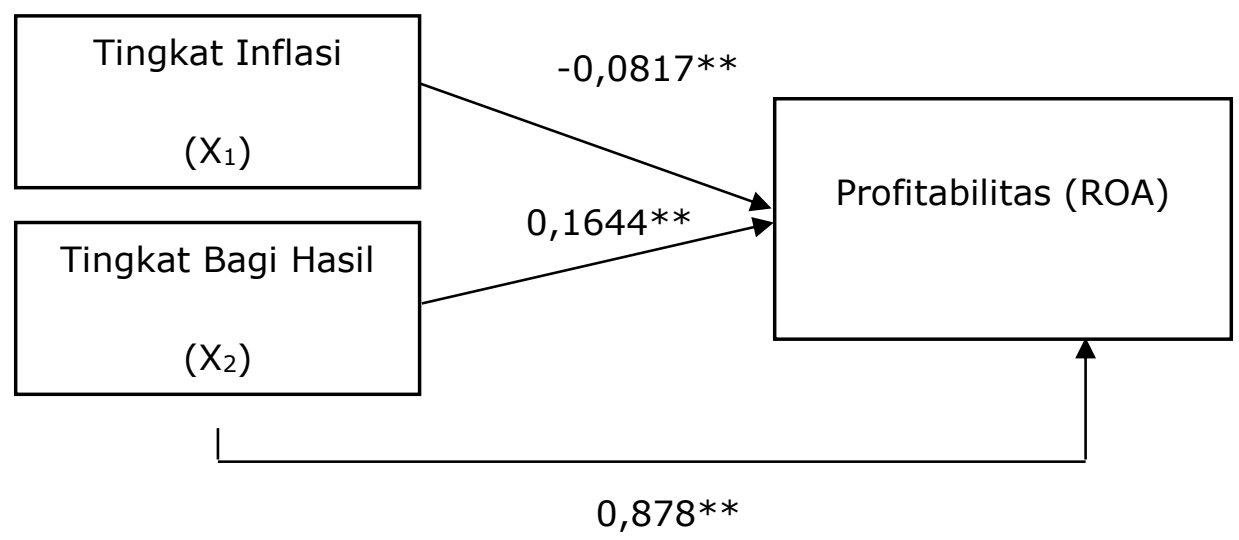

Gambar 10. Hasil Paradigma Penelitian

\section{PENUTUP}

Berdasarkan penelitian yang telah dilakukan oleh penulis, menggunakan data inflasi di Bank Indonesia (BI) dan data laporan keuangan PT Bank Muamalat Indonesia Tbk., PT BRI Syariah Tbk., PT Bank Bukopin Syariah Tbk., PT BNI Syariah Tbk., dan PT BCA Syariah, Tbk. dengan periode penelitian selama delapan tahun, mulai dari tahun 2011 sampai dengan tahun 2018, maka kesimpulan penulis dari hasil penelitian ini memberikan solusi pengaruh dari dua variabel independen yaitu Tingkat Inflasi dan Tingkat Bagi Hasil terhadap Profitabilitas yang diukur dengan indikator Return on Asset (ROA) adalah sebagai berikut :

1. Hasil penelitian yang telah dilakukan penulis bahwa Tingkat Inflasi berpengaruh negatif dan signifikan terhadap Return On Asset (ROA) pada PT Bank Muamalat Indonesia Tbk, PT BRI Syariah Tbk, PT Bank Bukopin Syariah Tbk, PT BNI Syariah Tbk, dan PT BCA Syariah. Dari hasil pengolahan data panel dengan Eviews variabel Tingkat Inflasi terhadap Return On Asset (ROA) diperoleh nilai signifikansi sebesar 0,0012 atau 0,12 \% yang berada di bawah 5\% dan koefisien korelasinya -0,0817. Artinya variabel Tingkat Inflasi berpengaruh negatif dan signifikan terhadap variabel Return On Asset (ROA). Hal ini dikarenakan jika tingkat inflasi tinggi, maka profitabilitas (ROA) bank syariah akan menurun.

2. Hasil penelitian yang telah dilakukan penulis bahwaTingkat Bagi Hasil pada PT Bank Muamalat Indonesia Tbk, PT BRI Syariah Tbk, PT Bank Bukopin Syariah Tbk, PT BNI Syariah Tbk, dan PT BCA Syariah berpengaruh positif dan signifikan terhadap Return On Asset (ROA), Dari hasil pengolahan data panel dengan Eviews variabel Tingkat Bagi Hasil terhadap Return On Asset (ROA) diperoleh nilai signifikansi sebesar 0,0000 atau 0\% yang berada di bawah 5\%. Artinya variabel Tingkat Bagi Hasilberpengaruh positif dan signifikan terhadap variabel Return On Asset (ROA). Hal ini dikarenakan jika tingkat bagi hasil naik, maka profitabilitas (ROA) bank syariah akan naik, dan jika tingkat bagi hasil turun maka profitabilitas (ROA) bank syariah juga menurun.

3. Hasil penelitian yang telah dilakukan penulis bahwa Tingkat Inflasi dan TingkatBagi Hasil pada PT Bank Muamalat Indonesia Tbk, PT BRI Syariah Tbk, PT Bank Bukopin Syariah Tbk, PT BNI Syariah Tbk, dan PT BCA Syariah berpengaruh positif dan signifikan terhadap Return On Asset (ROA), Dari hasil pengolahan data panel dengan Eviews variabel Tingkat Inflasi dan Tingkat Bagi Hasil terhadap Return On Asset (ROA) diperoleh nilai signifikannya sebesar 0,0000 atau 0\% yang berada di bawah 5\%. Artinya variabel Tingkat Inflasi dan Tingkat Bagi Hasilberpengaruh positif dan signifikan terhadap variabel Return On Asset (ROA). 
DAFTAR PUSTAKA

[1] Aan Komariah dan Djam'an Satori. (2011). Metode Penelitian Kualitatif. Bandung: Alfabeta.

[2] Apsari, M. (2019). PENGARUH INFLASI, BI RATE DAN KURS TERHADAP PROFITABILITAS PERBANKAN SYARIAH DI INDONESIA (Studi Pada Perbankan Syariah Yang Terdaftar di Bank Indonesia Tahun 2013 -2017). Skripsi, Universitas Mercu Buana Yogyakarta.

[3] Badan Pusat Statistik. Tabel Dinamis Subjek Inflasi. [Tersedia pada https://www.bps.go.id/], [diakses pada tanggal 28 Mei 2020].

[4] Bank Indonesia. Inflasi. [Tersedia pada https://www.bi.go.id ], [diakses pada tanggal 09 September 2019].

[5] Bank Indonesia. Laporan Inflasi (Indeks Harga Konsumen). [Tersedia padahttps://www.bi.go.id ], [diakses pada tanggal 09 September 2019].

[6] Bank Indonesia. Undang-Undang Tentang Perbankan No.10 Tahun 1998. [Tersedia pada https://www.bi.go.id ], [diakses pada tanggal 09 September 2019].

[7] Bank Indonesia. Undang-Undang Tentang Perbankan Syariah No.21 Tahun 2008. [Tersedia pada https://www.bi.go.id ], [diakses pada tanggal 09 September 2019].

[8] Bastari, Sella Pritalova Petri. (2015). ANALISIS PENGARUH TINGKAT INFLASI, BI RATE DAN BAGI HASIL TERHADAP JUMLAH SIMPANAN MUDHARABAH PADA BANK UMUM SYARIAH. STIE PERBANAS.

[9] Boyke Fitriadi. (2014). Tinjauan Atas Sistem Informasi Akuntansi Pada Transaksi Pembelian Bahan Baku Pada PT. Bumi Bersama. Digital Library, UNIKOM.

[10] Danang, Sunyoto. (2013). Metodologi Penelitian Akuntansi. Bandung: PT Refika.

[11] Dantes, Nyoman. (2012). Metode Penelitian. Yogyakarta: ANDI

[12] Dery Ariswanto. (2018). Makalah Equivalent Rate dan Perhitungannya. [Tersedia pada http://leesyailendranism.blogspot.com] [diakses pada tanggal 05 November 2019].

[13] Dewan Syariah Nasional. FATWA DEWAN SYARIAH NASIONAL. [Tersedia pada https://dsnmui.or.id/] [diakses pada tanggal 24 Juni 2020].

[14] Duraj, Moci. (2015). Factors Influencing The Bank Profitability - Empirical Evidence From Albania. Asian Economic and Financial Review.

[15] Effendi. (2018). PENGARUH RASIO KEUANGAN DAN VARIABEL MAKRO EKONOMI TERHADAP KONDISI PROFITABILITAS BANK MUAMALAT INDONESIA TAHUN 2004-2014. Perbanas Review. Vol. 3, No. 1.

[16] Ghozali, Imam. (2016). Aplikasi Analisis Multivariete Dengan Program IBM SPSS 23 Edisi 8. Semarang: Badan Penerbit Universitas Diponegoro.

[17] Irfan, Arifin Achmad. (2016). ANALISIS PENGARUH INFLASI DAN SUKU BUNGA BANK INDONESIA TERHADAP KINERJA KEUANGAN BANK UMUM SYARIAH DI INDONESIA (PERIODE 2012-2014). Other thesis, IAIN SALATIGA.

[18] Irham, Fahmi. (2014). Analisis Laporan Keuangan. Cetakan Keenam. Bandung: Alfabeta.

[19] Kasiram, Moh. (2008). Metodologi Penelitian. Malang: UIN-Malang Pers.

[20] Kasmir. (2012). Dasar-dasar Perbankan. Jakarta: Rajawali Pers.

[21] Kasmir. (2013). Analisis Laporan Keuangan. Jakarta: Rajawali Pers.

[22] Kasmir. (2014). Analisis Laporan Keuangan. Edisi Satu. Cetakan Ketujuh. Jakarta : PT Raja Grafindo Persada.

[23] Kasmir. (2016). Analisis Laporan Keuangan. Jakarta: Raja Grafindo Persada.

[24] Kusumah, Reza Prawira. (2013). Pengaruh Tingkat Bagi Hasil Terhadap Profitabilitas Bank Syariah (Studi Pada Bank Syariah Mandiri). Repository Indonesia University of Education.

[25] N. Nadliroh. 2013. PENGARUH TINGKAT BAGI HASIL TERHADAP PROFITABILITAS PERBANKAN SYARIAH (Studi Kasus Pada Bank Mega Syariah).
Inflation Rate and Profit

Sharing Rate on Sharia Commercial Bank Profitability 
Inflation Rate and Profit Sharing Rate on Sharia Commercial Bank Profitability

366
[26] Otoritas Jasa Keuangan (OJK). (2017). Perbankan Syariah dan Kelembagaannya. [Tersedia pada https://www.ojk.go.id], [diakses pada 13 September 2019].

[27] Otoritas Jasa Keuangan (OJK). (2020). Statistik Perbankan Syariah. [Tersedia pada https://www.ojk.go.id], [diakses pada 10 April 2020].

[28] R. Gustiono. (2017). Pengaruh Variabel Moneter (Inflasi, Suku Bunga, dan Nilai Tukar) Terhadap Profitabilitas Bank Pembangunan Daerah Sebelum dan Setelah Otonomi Daerah (Studi Kasus Pada Bank Jatim, Bank Jateng, dan Bank BJB Periode 1990-2012). Jurnal Ilmiah Mahasiswa FEB.

[29] Slamet, Agung. (2014). Pengaruh Pembiayaan Bagi Hasil, Pembiayaan Jual Beli, FDR, dan NPF Terhadap Profitabilitas Bank Umum Syariah di Indonesia. Accounting Analysis Journal $3(4)$.

[30] SlametWiyono. (2019). Bagi Hasil Bank Syariah. Saleema Institute [Tersedia pada http://slametwiyono.com], [diakses pada 04 November 2019].

[31] S. Nasution. (2010). Metodologi Research (Penelitian Ilmiah). Jakarta: Bumi Aksara. Hal. 113

[32] Sudarsono, Heri. (2008). Bank dan Lembaga Keuangan Syari'ah. Yogyakarta: Ekonisia.

[33] Sudarsono, Heri. (2012). Bank dan Lembaga Keuangan Syari'ah. Edisi Keempat. Yogyakarta: Ekonisia.

[34] Sugiyono. (2012). Metode Penelitian Kuantitatif Kualitatif dan R\&D. Bandung: Alfabeta.

[35] Sugiyono. (2014). Metode Penelitian Kuantitatif Kualitatif dan R\&D. Bandung: Alfabeta.

[36] Sugiyono. (2017). Metode Penelitian Kuantitatif, Kualitatif, dan R\&D. Bandung: Alfabeta.

[37] Umrotul, Irsad, dan Haerudin. (2017). Analisis Pengaruh Inflasi, Suku Bunga, Nilai Tukar Terhadap Kinerja Bank Syariah BUMN (Periode 2014-2017). MALIA: Journal of Islamic. Vol. 1 No. 7.

[38] https://www.bankmuamalat.co.id/

[39] https://www.brisyariah.co.id/

[40] https://www.syariahbukopin.co.id/

[41] https://www.bnisyariah.co.id/

[42 https://www.bcasyariah.co.id/ 